\title{
Callucina and Pseudolucinisca (Mollusca: Bivalvia: Lucinidae) from Australia: revision of genera and description of three new species
}

\author{
Emily A. Glover and John D. Taylor \\ Department of Zoology, "The Natural History Museum, London SW7 5BD, \\ United Kingdom. Email: emilyglover@mac.com; j.taylor@nhm.ac.uk
}

\begin{abstract}
Three new species of lucinid bivalves are described from Australia. Two of these are assigned to the genus Callwima, previously known living only from the Western Atlantic Ocean. In Westem Australia, Callucina limnaei ranges from the Houtman Abrolhos Islands northwards to the Dampier Archipelago. Callacima brittoni is recorded from islands on the Great Barrier Reef, Queensland. Another Indian Ocean species, C. winckworthi (Viader 1951) is recognized from Mauritius. The third new species, Pseudolucinisca anam, was previously confounded with the South and Western Australian endemic species, P. lacteola. Psedudoluinisa anmi is distributed from Geographe Bay to Port Hedland while the more southerly range of $P$. lacteola extends from western Victoria to Cape Leeuwin, Western Australia. Revised descriptions are given for the genera Callucina and Pseudolucinisca. Callucina species have a fossil history in the Cenozoic of Europe and North America and the living Australian and Mauritian species may be relicts from a wider distribution in the Cenozoic Tethyan Ocean.
\end{abstract}

\section{INTRODUCTION}

The discovery of chemosymbiosis in lucinid bivalves in the mid 1980s stimulated renewed interest in the systematics of the previously rather neglected family Lucinidae, with 57 new species and 28 new genera described in the last ten years. Within Australia, Lamprell and Whitehead (1992) and Lamprell and Healy (1998) list 33 species of Lucinidae. Since then several unusual taxa have been described from Western Australia including Rasta thiophila, Cardiolucina australopilula, Plicolucina flabellata, Lamellohcina pilbara and Pillucina australis Taylor and Glover (1997a, 1997b, 2002), Glover and Taylor (2001); Glover, Taylor and Slack-Smith (2003). Additionally, new species and new records of Andontia have been recorded from tropical eastern Australia (Taylor and Glover 2005).

In this paper we describe two new Australian species of Callucina Dall 1901, a genus previously known living only in the Western Atlantic, and also a recognise a new species of Pseudolucinisca Chavan 1959, previously confounded with Pseudolucinisca lacteola (Tate 1897), a species endemic to south and southwestern Australia. Pseudolucinisca was hitherto a monospecific genus, usually classified as a subgenus of Callucina (Chavan 1969; Lamprell and Whitehead 1992). It is unfortunate that only dead-collected shell material is available for these new species, likewise for the western Atlantic Callucina keenac, precluding any anatomical observations or molecular analysis.

As neither Callucina nor Psendolucinisca are welldefined genera, we provide new descriptions and illustrations of the type species. Some confusion exists because in the most recent comprehensive generic revision Chavan (1969, figures E3.10) unfortunately figured an Eocene fossil, "Callucina" hoernesi (Deshayes 1857), as the example of Callucina. But this has characters (e.g. both anterior and posterior lateral teeth) not present in the type species which he did not illustrate.

The phylogenetic positions of these genera are interesting; in the case of Pseutolucinisca, based on P. lacteola, molecular analysis (Williams of al. 2004) indicated it was in a basal clade, sister to the Anodontia group and quite distinct from the majority of shallow water lucinids, such as Codakin, Ctena, Lucina and Loripes. Earlier, from morphological evidence, Bretsky (1976: 258) suggested that Callucina and Parvilucina were closely related and derived from a common ancestor in the late Cretaceous or early Cenozoic. Unfortunately, this hypothesis has not been tested by molecular techniques because no Callacina specimens have been available for analysis.

Lucinids assigned to Callucina have a putative fossil history into the Early Cretaceous (Chavan $1969)$ but all these records need re-evaluation. Nevertheless, Eocene fossils such as Callucina papuracen (Lea 1833) from the southern USA are similar to the type species, C. kernae. Callucinalike lucinids were present in the Eocene of Europe but by the Miocene were represented only in the Americas (Chavan 1959; Bretsky 1976).

From Australia, Pseludolucinisca lacteola has been 
recorded from the Late Pliocene of southwestern Australia (Ludbrook 1978). Additionally Ludbrook (1955) plate 2, figure 10) illustrates Callucina balcombica (Cossmann 1912) also from Pliocene of Adelaide and Gippsland, Victoria. Although this species resembles Callucina in external shell form, Chavan (1961) classified it within the new genus Callucinella on the basis of hinge teeth.

\section{MATERIALS AND METHODS}

The specimens examined for this study are lodged in the following institutions: Australian Museum, Sydney (AMS); Academy of Natural Sciences, Philadelphia (ANSP); The Natural History Museum, London (BMNH); Museum Victoria, Melbourne (MV); South Australian Museum, Adelaide (SAM); Western Australian Museum, Perth (WAM).

Shells were examined by conventional optical microscopy. Tissue samples of ctenidia and posterior apertures of a single specimen of Pseudolucinisca lacteola collected at Esperance Western Australia were fixed in a $2.5 \%$ glutaraldehyde solution in phosphate buffer, critical point dried through an ascending acetone series, sputter coated with gold and examined by scanning electron microscopy.

The following abbreviations were used throughout the text: H - shell height; L shell length; LV - left valve; RV - right valve; $\mathrm{T}$ - tumidity of single valve, $\mathrm{m}$ - metre. All measurements of specimens in $\mathrm{mm}$.

\section{SYSTEMATICS}

\section{Superfamily Lucinoidea Fleming 1828 \\ Family Lucinidae Fleming 1828 \\ Callucina Dall 1901}

Phacoides (Callucina) Dall 1901: 806.

Lucina (Callucina): Chavan 1938: 220; Bretsky 1976: 257.

Callucina: Chavan 1969: N494.

\section{Type species}

Lucina radians Conrad 1841, by original designation (junior homonym of $L$. radians Bory de St Vincent 1824; replacement name Callucina keenae (Chavan in Cox et al. 1971: N1215). Holotype, 1 right valve (ANSP 30603) from near Magnolia, Natural Well, Duplin County North Carolina, USA. Pliocene.

\section{Diagnosis}

Subcircular, sculpture of closely spaced commarginal lamellae, fine radial striations particularly at anterior and posterior. Lateral teeth absent, 2 cardinal teeth in LV; single cardinal in
RV; adductor muscle scar detached ventrally from pallial line for $1 / 5$ to $1 / 2$ of length, inner shell margin finely denticulate.

Because of some confusion concerning the characters of Callucina we describe the type species below (Figures 1, 2, A-D, 3A).

Callucina keenae, shell small to medium size ( $\mathrm{H}$ to $23.0, \mathrm{~L}$ to 22.4 ) subcircular, usually slightly longer than high, $\mathrm{H} / \mathrm{L}$ mean 0.97 , moderately inflated, $T / L$ mean 0.26 ). Umbones prominent, central. Sculpture of closely spaced, regular, low commarginal lamellae. Interspaces narrower than ridges. Growth halts prominent. Radial sculpture of faint striations, particularly at anterior and posterior parts of shell. Sulci or demarcated dorsal areas absent. Ligament broad, set in shallow nymph. Lunule heart-shaped, impressed, slightly asymmetric, wider in RV, overlying LV. Hinge with lateral teeth absent, RV with one large, posterior, bifid cardinal tooth, separated by a large socket from projecting lunule. LV with large, slightly bifid, anterior cardinal, separated by a socket from thin, posterior cardinal at margin of hinge plate. Anterior adductor scar moderately long, broad, ventrally detached from pallial line for half of length (Figure 3A). Anterior pedal muscle scar separate from adductor; posterior adductor scar subovate. Pallial line irregularly lobate dorsally, almost discontinuous. Inner shell margin finely denticulate. Inner shell between edge and pallial line with fine radial grooves. Shell white, internal margin glossy outside of pallial line.

\section{Remarks}

Because of previous misunderstanding we have taken a more restricted concept of Callucina than used by previous authors (e.g. Chavan 1937-1938, 1969), for example, excluding species with lateral teeth. The type species was described from a Pliocene fossil but the shells are morphologically inseparable from living bivalves referred to this species from the southern USA and Caribbean. Chavan (1969 figures E2, 9ab) confusingly illustrated Callucina hoernesi (Deshayes) from the Eocene of France as an example of Callucina but this species has characters not found in the type species, such as the presence of both anterior and posterior lateral teeth and an elongate anterior adductor scar, ventrally detached from the pallial line for about $3 / 4$ of length.

Callucina keenae ranges in the Western Atlantic from North Carolina to Brazil at depths from the shallow subtidal to $183 \mathrm{~m}$ (Britton 1970) and is generally thought to be the only living species of Callucina. Britton (1970) included Callucina bermudensis Dall 1901 (plate 39, figure 5) from Bermuda, introduced as a new name for Lucina lenticula Reeve 1850 (non L. lenticula Gould 1850) 


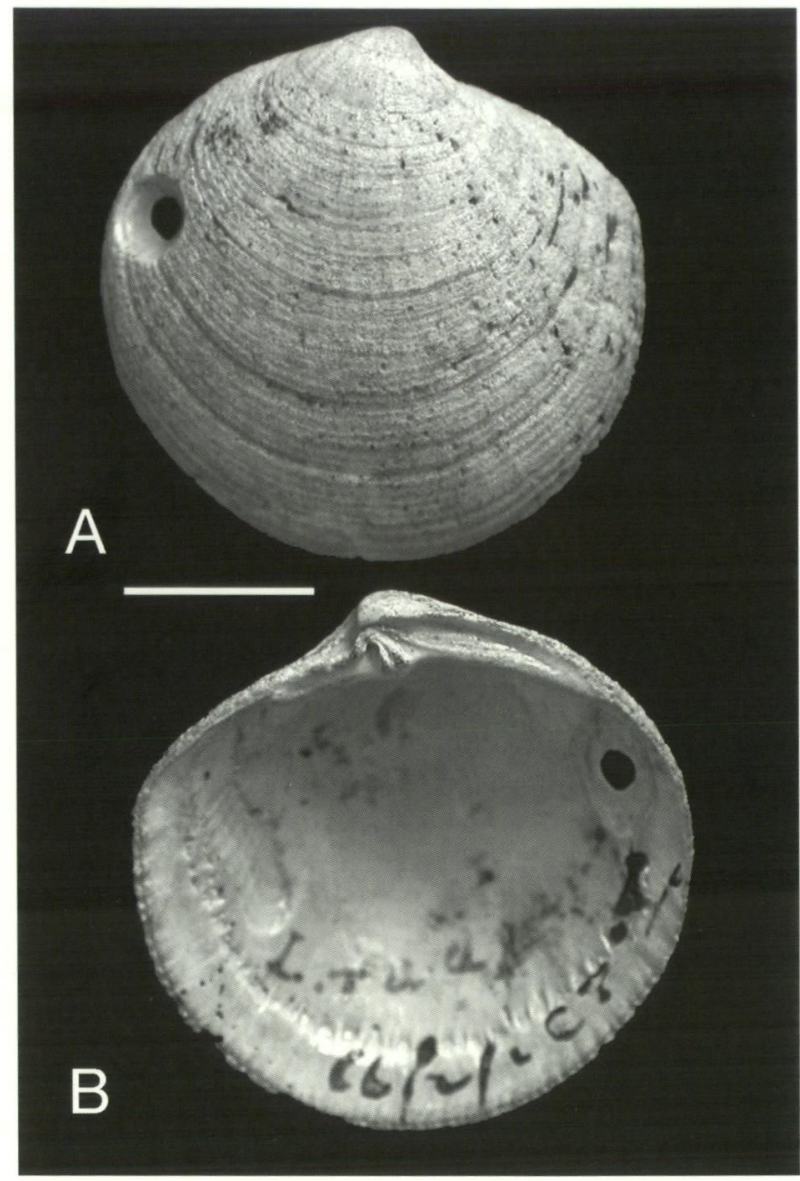

Figure 1 Holotype of Lucina radians Conrad 1841, the type species of Callucina (ANSP 30603), Pliocene, near Magnolia, Duplin County, North Carolina, U.S.A. Scale bar $=5 \mathrm{~mm}$.

but Dall writes that his specimens were encrusted with sediment and that no living specimens had come to his attention. However, these shells (USNM 41339) differ from C. keenae in sculpture, hinge teeth, characters of the anterior adductor scar and lack of marginal denticles. At least one of the two syntypes of L. lenticula (BMNH 1963171-2) appears live-collected (no locality given) and has characters of a small Lucinoma. Cavilinga lampra (Dall 1901) from the eastern Pacific has sometimes been placed in Callucina but this species possesses both anterior and posterior lateral teeth (see discussion in Bretsky 1976: 271).

Most fossil species assigned to Callucina need re-evaluation in relation to the type species. Lucina papyracea Lea 1833 from the Middle Eocene of Alabama (see Bretsky 1976, plate 27 figures 5-7) closely resembles the type species and may be regarded as an early Callucina. A number of other species from the Paleocene and Eocene included in Callucina by Chavan (1938: 253) possess lateral teeth and elongate, detached adductor muscle scars and can be excluded.

\section{Callucina linnaei sp. nov.}

Figures 2E-L, 3B, 4

Material examined

Holotype

Australia: Western Australia: 1 shell (H 26.5, L 28.8, T 8.0), Dampier Archipelago, Lady Nora Island, $20^{\circ} 28^{\prime} \mathrm{S}, 116^{\circ} 40^{\prime} \mathrm{E}$, December 1971, B.R. Wilson (WAM S13402).

\section{Paratypes}

Australia: Western Australia: 4 shells, 1 valve (H 27.4, L 28.9; H 26.3, L 27.1; H 19.7, L 21.3; H 21.7, L 24.3; H 22.2, L 24.1), Montebello Islands, east side Hermite Island, 20³1'35'S, 115 33'03"E, $4 \mathrm{~m}$, August 1993, S. Slack-Smith (WAM S12506).

\section{Other material examined}

Australia: Western Australia: 2 shells, Goss Passage, Beacon Island, Houtman Abrolhos Islands, 28²8'29"S, 11346'46"E, 25 m, April 1978 (WAM S12507); 1 shell, Middle Channel, Easter Group, Houtman Abrolhos Islands, 28³5'S, 11345'E, 38 m, March 1963 (WAM S13404); 5 valves, NE of Leos Island, Easter Group, Houtman Abrolhos Islands 28 $40^{\prime} 05^{\prime \prime} \mathrm{S}, 113^{\circ} 54^{\prime} \mathrm{E}, 42 \mathrm{~m}$, August 1977 (WAM S13405); 1 valve, N. Muiron Island, North West Cape, 2139'19"S, 114²' 27"E, 6-13 m, 24 August 1995, (WAM S13403); 1 valve, lagoon, S.W. of Hermite Island, Montebello Islands, 20³0'09"S, 115²9'59"E, 3 m, August 1993 (WAM S13406).

\section{Diagnosis}

Compared to C. keenae, C. linnaei is larger, with broader, more widely spaced commarginal lamellae and fewer radial striations between them. The anterior adductor muscle scar is less ventrally detached from the continuous pallial line. Callucina linnaei differs from C. brittoni (see below) from Queensland in its larger size, less inflated shell and much coarser commarginal lamellae.

\section{Description}

Shell medium-sized, thick-shelled, $\mathrm{H}$ to 27.4 $\mathrm{mm}$, L to $28.9 \mathrm{~mm}$, subcircular, slightly longer than high, H/L mean 0.93 range $0.89-0.97$; moderately inflated, $\mathrm{T} / \mathrm{L}$ mean 0.27 , range $0.24-$ 0.30 . Ventral, anterior and posterior margins rounded. Umbones slightly anterior of mid-line, prosogyrate, prominent. Sculpture of numerous low, rounded closely spaced, commarginal lamellae with prominent growth halts. Lamellae divide and anastomose to the anterior and posterior. Commarginal lamellae crossed by faint radial striations, particularly to anterior and 


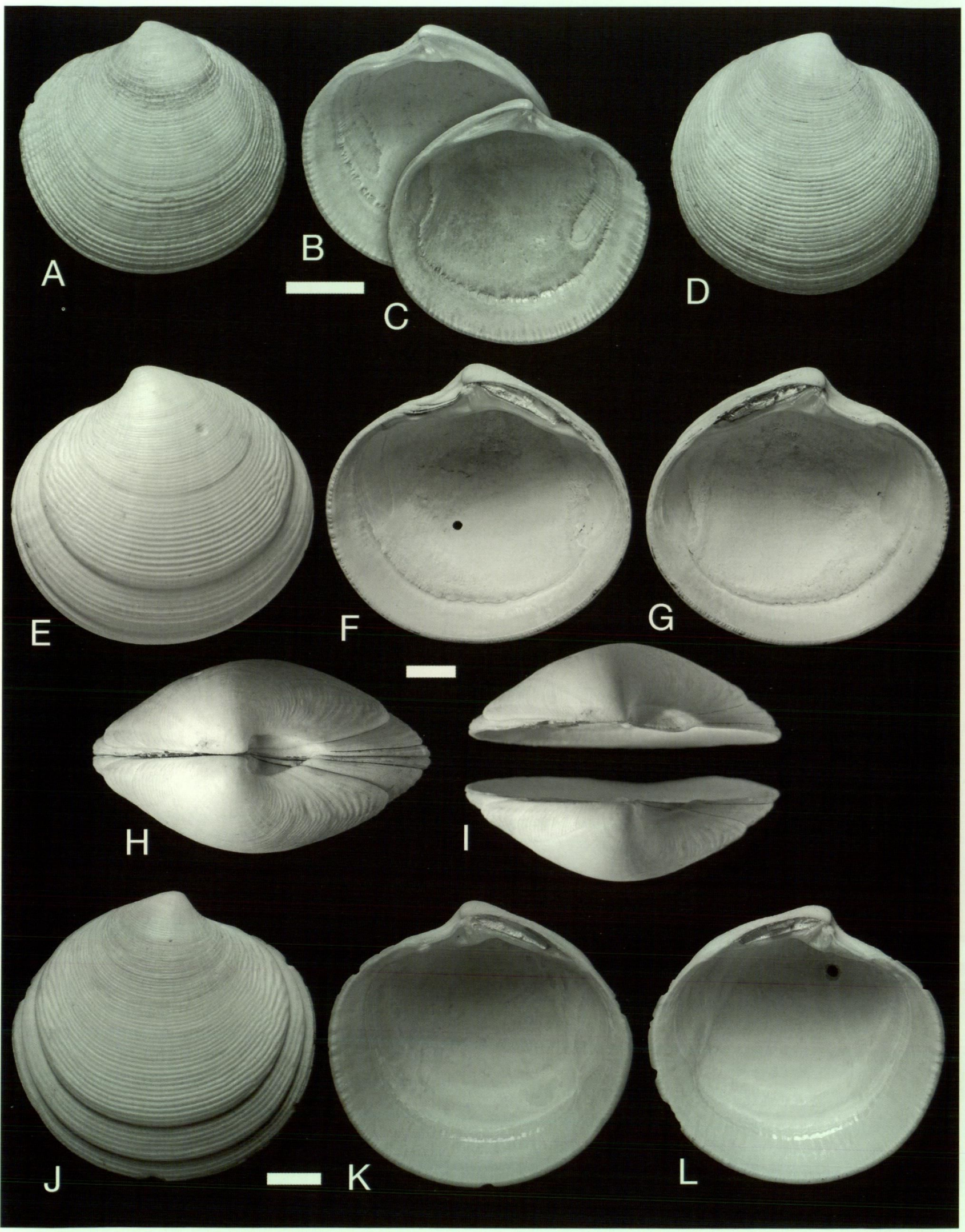

Figure 2 A-D, Callucina keenae Chavan 1971 West Indies, Carpenter Collection (BMNH 65.1.27.4); E-L, Callucina linnaei new species: E-I, holotype (WAM S12506), Lady Nora Island, Dampier Archipelago, Western Australia; E, exterior of left valve; F, G, valve interiors; H, dorsal view with valves closed; I, dorsal view, valves parted; J-L, paratype (WAM S12506) Hermite Island, Monte Bello Islands, Western Australia; J, exterior of right valve; K, $\mathrm{L}$, valve interiors. Scale bars $=5 \mathrm{~mm}$ 
posterior and, in some specimens, by low rounded ribs at anterior. Dorsal areas not demarcated except by slight thickening and anastomosing of commarginal lamellae. Lunule impressed, narrow, heart-shaped, asymmetrical, smaller in RV but overlies LV. Ligament large, lying in deep nymph, not protruding above dorsal margin. Hinge plate thick, RV with single, large, bifid cardinal tooth, LV with two cardinal teeth, the posterior larger and slightly bifid, the anterior smaller. Lateral teeth absent in both valves. Anterior adductor muscle scar short, ventrally detached from pallial line for only $1 / 5$ of length (Figure 3B). Pallial line entire, but lobate dorsally. Inner shell margin very finely denticulate. Exterior colour white, interior hinge area and margin outside pallial line often yellowish.

\section{Distribution}

The species has been found in Western Australia from the Houtman Abrolhos Islands to Dampier Archipelago (Figure 4).

\section{Etymology}

The species is named in honour of Carl Linnaeus.

\section{Callucina brittoni sp. nov.}

Figures $3 \mathrm{C}, 4,5$

\section{Material examined}

Holotype

Australia: Queensland: 1 shell (H 14.9, L 15.6, T 4.8), northern Great Barrier Reef, Lizard Island, South Island, $14^{\circ} 42^{\prime} \mathrm{S}, 145^{\circ} 27^{\circ} \mathrm{E}, 3-18 \mathrm{~m}$ on coral and rubble on southern face of fringing reef, December 1974, W.F. Ponder, P.H. Colman and I. Loch (AMS C 360666)

\section{Paratypes}

Australia: Queensland: 33 valves, northern Great Barrier Reef, Michaelmas Cay, 16.36's, $145^{\circ} 59^{\prime} \mathrm{E}$, GBR Boring Expedition, May-June 1926, T. Iredale and G.P. Whitley (AMS C053648); 39 valves, same locality (AMS C053649). Measurements of selected shells (H 16.1, L 17.0; H 15.1, L 16.0; H 15.5 L 16.4; H14.7, L 15.6).

\section{Other material exanined}

Australia: Queensland: 2 valves, $3 \mathrm{~km} \mathrm{NE}$. of Bylund Cay, Swain Reefs, Great Barrier Reef, $21^{\circ} 42^{\prime} \mathrm{S}, 1522^{\circ} \mathrm{E}, 64-73 \mathrm{~m}, 1962$ (AMS C360665).

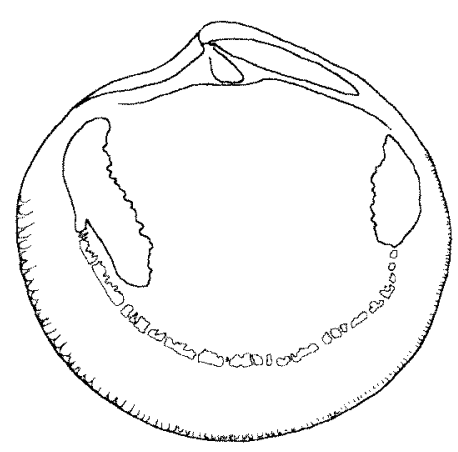

A. Callucina keenae

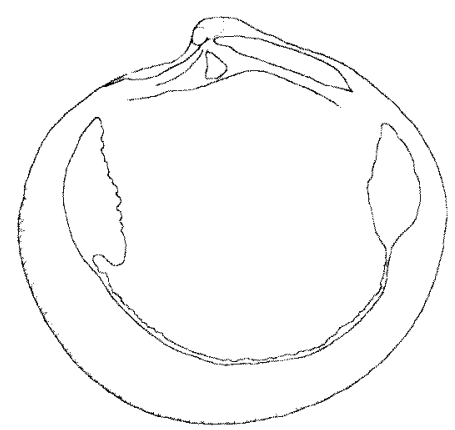

D. Callucina winckworthi

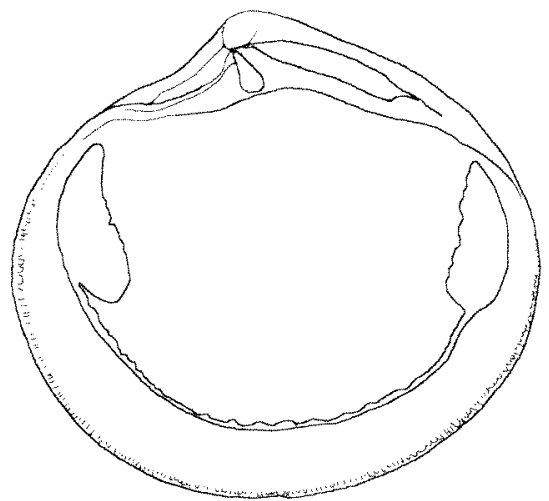

B. Callucina linnaei

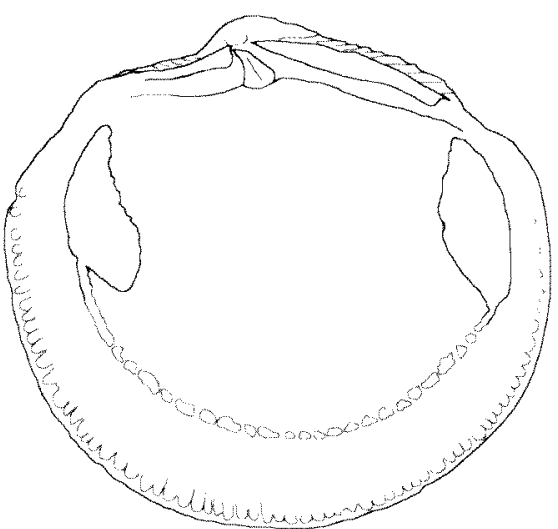

E. Pseudolucinisca lacteola

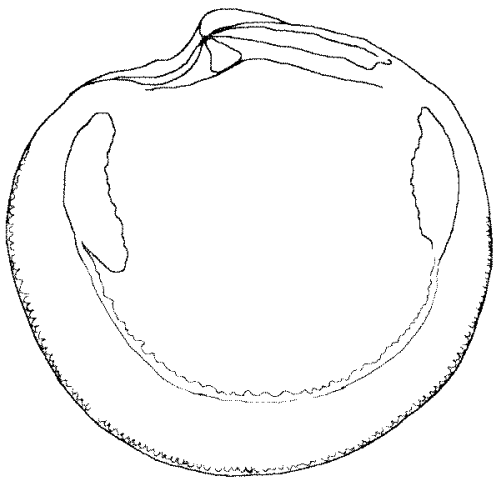

C. Callucina brittoni

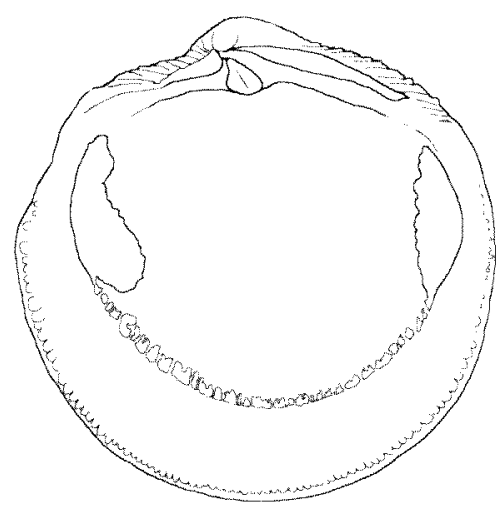

F. Pseudolucinisca wami

Figure 3 Outline drawings of interiors of right valves of Callucima and Psudolucinisca species. Not to scale. 


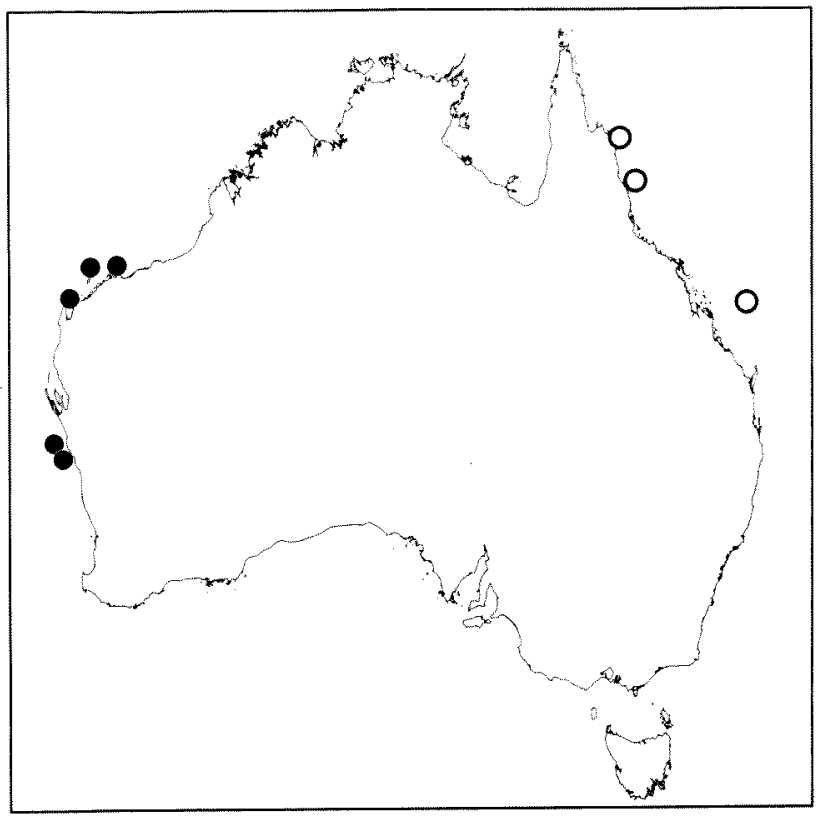

Figure 4 Map showing distribution of Callucina species. Callucina linnaei $(\mathbf{O})$, C. brittoni $(\bigcirc)$.

\section{Diagnosis}

Compared with Callucina linnaei, C. brittoni is smaller, thinner shelled, slightly more inflated, with lower, narrower and more abundant commarginal lamellae. In both species, the asymmetry of the lunule is variable.

\section{Description}

Shell small, $\mathrm{H}$ to $17.0, \mathrm{~L}$ to 17.4 , subcircular, $\mathrm{H} / \mathrm{L}$ mean 0.95, range 0.92-1.01, moderately inflated, $\mathrm{T} / \mathrm{L}$ mean 0.33 , range $0.29-0.34$. Ventral, anterior and posterior margins rounded. Umbones at midline, prosogyrate, prominent. Dorsal areas not demarcated. Sculpture of numerous fine, rounded, closely spaced, commarginal lamellae, with growth halts prominent. Commarginal lamellae crossed by faint radial striations, particularly in anterior and posterior areas. Lunule impressed, short, asym-metric, wider RV overlies longer LV (Figure 5D, K). Ligament robust, in shallow nymph. Hinge, RV with single, large cardinal tooth; LV with two cardinal teeth, the anterior smaller. Lateral teeth absent in both valves (Figure 5E,F). Anterior adductor muscle scar short, ventrally detached from pallial line for $1 / 4$ of length (Figure 3C), posterior adductor scar ovoid. Pallial line entire, with slightly lobate dorsal margin. Inner shell margin finely denticulate with radial grooves. Exterior colour white, interior of shell of ten glossy, pale yellow.

\section{Distribution}

This species has been found only in the Great Barrier Reef, Queensland (Figure 4).

\section{Etymology}

This species is named for the late Joseph (Joe) Britton who wrote a fine but unpublished Ph.D. thesis on taxonomy of Lucinidae (Britton 1970).

\section{Callucina winckworthi (Viader 1951) Figures 3D, 6}

Lucina (Phacoides) winckworthi Viader 1951: 135, plate 4 , figures $1-3$.

\section{Material examined}

Mauritius: One shell (Figure 6) and three valves sent by R. Viader to R. Winckworth (BMNH 20080324). Four valves, Cassis, collected by R. Viader 1950 (BMNH 20080323). 9 valves, Flic en Flac (BMNH 20080322). Three valves, Biggs Collection (BMNH 20080325).

\section{Description}

Shell small, $\mathrm{H}$ to $13.5 \mathrm{~mm}, \mathrm{~L}$ to $13.8 \mathrm{~mm}$, subcircular, $\mathrm{H} / \mathrm{L}$ mean 0.98 , range $0.96-1.00$, moderately inflated, $\mathrm{T} / \mathrm{L}$ mean 0.33 , range 0.32 0.36 . Ventral, anterior and posterior margins rounded. Umbones at mid-line, prosogyrate, prominent, protruding. Dorsal areas not demarcated. Sculpture of numerous, rounded, closely spaced, commarginal lamellae, with growth halts prominent. Commarginal lamellae crossed by faint radial striations. Lunule short, heart-shaped, impressed, asymmetric, wider in RV. Ligament short, robust, in shallow nymph. Hinge, RV with single, large cardinal tooth; LV with two cardinal teeth, the anterior larger. Lateral teeth absent in both valves. Anterior adductor muscle scar short, ventrally detached from pallial line for $1 / 5$ of length, posterior adductor scar ovoid. Pallial line entire. Inner shell margin finely denticulate. Exterior colour white to yellow, interior white, sometimes pale yelloworange on hinge and shell margin outside pallial line.

\section{Distribution}

Known only from Mauritius.

\section{Remarks}

Apart from the two new Australian species this is the only Callucina species known from the IndoWest Pacific Province. Compared to C. linnaei and C. brittoni it is much smaller, relatively higher than long, with more irregular commarginal lamellae. 


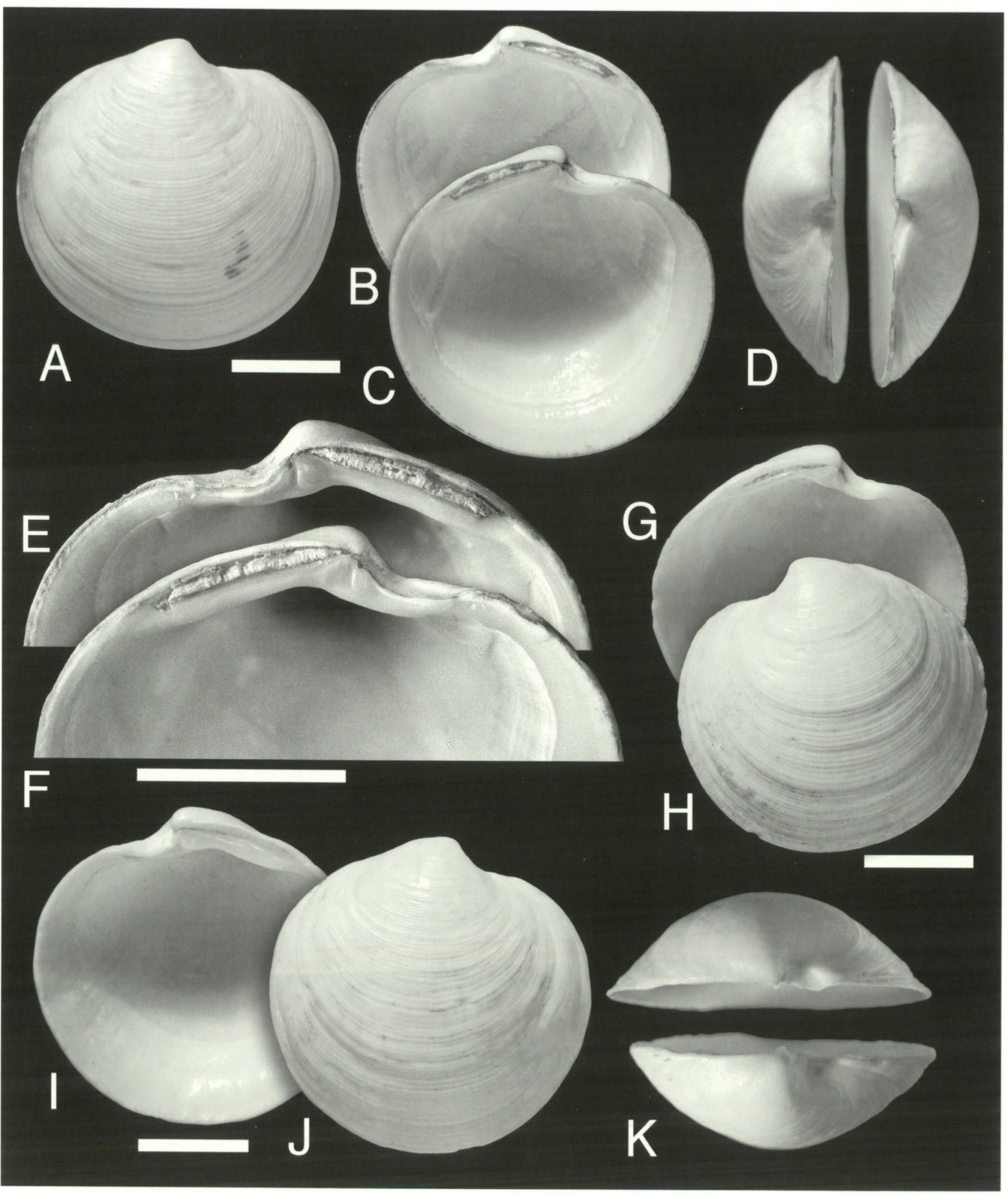

Figure 5 Callucina brittoni sp. nov. A-F. Holotype (AMS C 360666), South Island, Lizard Island, Great Barrier Reef, Queensland, Australia; A, exterior right valve; B,C, interior of both valves; D, dorsal view with valves parted; $\mathrm{E}, \mathrm{F}$, details of hinge of both valves; G-K, paratypes (AMS C 053648) Michaelmas Cay, Great Barrier Reef, Queensland; G, H, exterior and interior of left valve; I-J, paratype (AMS C 053648), interior and exterior of right valve; $\mathrm{K}$, dorsal view of $\mathrm{G}$ and $\mathrm{J}$. Scale bars $=5 \mathrm{~mm}$. 


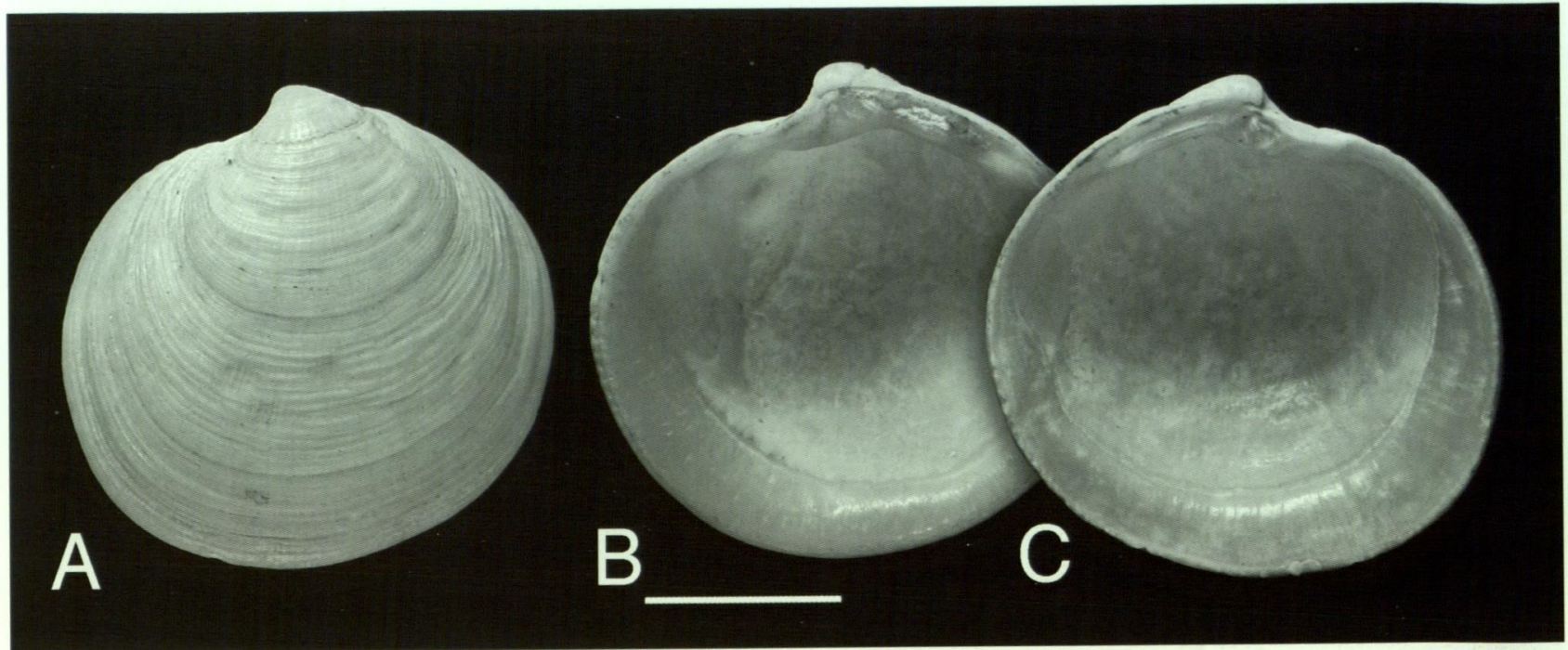

Figure 6 Callucina winkworthi (Viader 1951), Mauritius (BMNH 20080324). A Exterior of left valve, B. C, interior of right and left valves. Scale bar $=5 \mathrm{~mm}$.

\section{Pseudolucinisca Chavan 1959}

Callucina (Pseudolucinisca) Chavan 1959: 516.

\section{Type species}

Lucina lacteola Tate 1897 (= L. lactea Adams 1855 non Lamarck 1818; Lucina concentrica Adams and Angas 1863, non Lamarck 1806), by original designation.

\section{Diagnosis}

Subcircular in outline, sculpture of narrow, regularly spaced commarginal lamellae; lunule highly asymmetric, with arcuate flange projecting entirely from LV; lateral teeth absent, RV with single, large, bifid cardinal tooth; LV with posterior cardinal and vestigial anterior cardinal abutting lunule extension. Pallial line discontinuous, divided into irregular blocks. Shell margin denticulate.

\section{Remarks}

Although Pseudolucinisca is usually treated as a subgenus of Callucina it is uncertain if the two genera are related and here we treat the taxa as separate, distinct genera. Molecular data are published for Pseudolucinisca (Williams et al. 2004), but none are yet available for Callucina.

Chavan (1959) assigned the two Miocene species Lucina strigosa Michelotti, 1861 and L. michelotti Mayer, 1858 to Pseudolucinisca. Illustrations of these species (Sacco 1901: plate 20, figures 18-21; Cossmann and Peyrot 1909-1912: plate 28, figures 47-50) show lucinids with marked dorsal areas and prominent anterior lateral teeth, unlike the type, but they have large lunules, although from the figures it is impossible to say whether these are strongly asymmetrical.

\section{Pseudolucinisca lacteola (Tate 1897)}

Figures 3E, 7, 8, 10, 11

Lucina lactea A. Adams 1855: 225 (junior primary homonym of Lucina lactea Lamarck 1818).

Lucina concentrica A. Adams and Angas 1865: 426, plate 37, figure 19 (non L. concentrica Lamarck 1806).

Lucina lacteola Tate 1897: 48 (replacement name for L. lactea A. Adams).

Loripes lacteola (Tatè 1897): Hedley 1916: 161.

Codakia lacteola (Tate): May 1921: 18; Cotton and Godfrey 1938: 206, figure 219; Cotton 1961: 219, figure 226.

Callucina lacteola (Tate): May revised by Macpherson 1958: plate 7, figure 16; Ludbrook 1978: 51.

Callucina (Pseudolucinisca) lacteola (Tate): Chavan 1959: 516; Lamprell and Whitehead 1992: figure 116.

\section{Material examined}

Syntypes of Lucina lactea

Australia: Western Australia: 3 shells (H 21.423.8, L 22.4-24.0), Swan River and New Zealand (error), (BMNH 1963555/1-3).

\section{Syntypes of Lucina concentrica}

Australia: South Australia: 3 shells (H 19.620.8, L 21.5-21.7), St Vincent Gulf (BMNH 1870.10.26.33).

\section{Other material examined}

Australia: Victoria: Portland, West Victoria (AMS). South Australia: St Kilda, Adelaide 


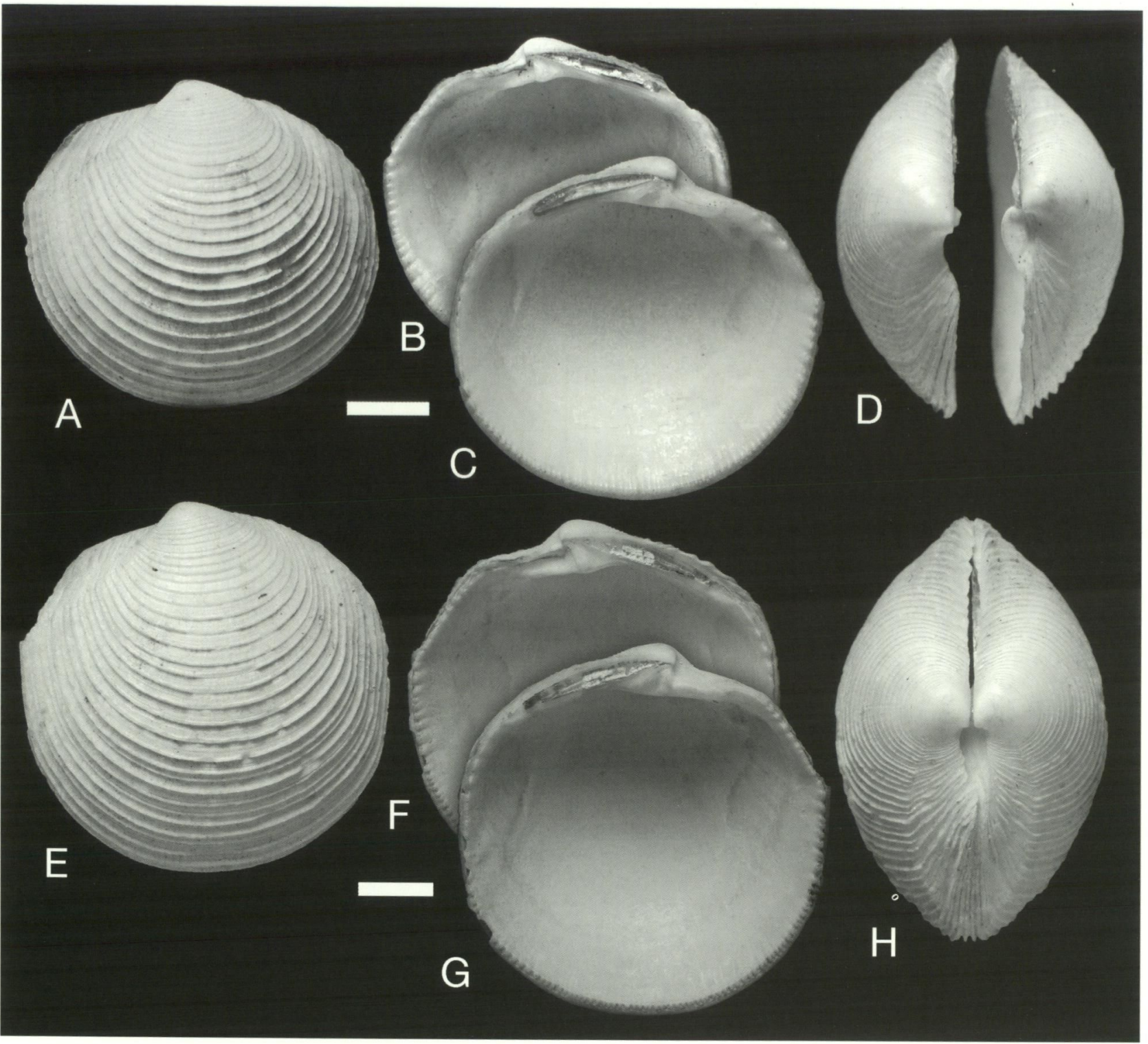

Figure 7 Pseudolucinisca lacteola (Tate 1897): A-D, syntype of Lucina lactea (BMNH 1963555/1-3): A, exterior left valve; B, C, interior of both valves; D, dorsal view of parted valves; E-H, syntype of L. concentrica Reeve, 1850 (BMNH 1870.10.26.33): E, exterior left valve; F, G, interior of both valves; $\mathrm{H}$, dorsal view. Scale bars $=5 \mathrm{~mm}$.

(BMNH); Holdfast Bay (AMS C39180); Normanville (AMS); West Beach (AMS C75726); St Vincent Gulf (AMS C 13784); Safety Bay (NMV), Largs Bay (NMV), Heydon Beach (NMV), Grange (NMV); Henley Beach (SAM), West Franklin Island, (SAM); Willunga (SAM); Scales Bay (SAM); Semaphore Beach, Adelaide (SAM); Outer Harbour (SAM); Kingston Park (SAM); Edithburgh, Yorke Peninsula (SAM); Port Lincoln. (NMV). Western Australia: between Eucla and Esperance, 79-147 m (AMS); North Twin Island and Middle Island, Recherche Archipelago (NMV); Duke of Orleans Bay (AMS); Mississippi Bay, Esperance (AMS); Lucky Bay, Cape le Grand (BMNH); Esperance Beach (BMNH); Two Peoples Bay, Albany (AMS); Shoal Bay, Albany (BMNH); Oyster Harbour,
Albany (WAM); Princess Royal Harbour, Albany (AMS); Emu Point, Albany (AMS); Torbay, Albany (WAM); Duke Head, Augusta (BMNH).

\section{Description}

Shell medium sized, $\mathrm{H}$ to 27.2 , L to 29.0, subcircular, H/L mean 0.96 range 0.91-0.99, inflated, T/L mean 0.34, range 0.29-0.39. Umbones rounded, central, low. Sculpture of regularly spaced, low, thin commarginal lamellae (6-8 lamellae per $5 \mathrm{~mm}$ shell height); with fine, radial lines in interspaces, mainly in posterior part of shell. Lunule, lanceolate, impressed, highly asymmetrical, with strong, arcuate flange of LV projecting into RV (Figure 7D). Anterior dorsal area demarcated by a low ridge and posterior area 

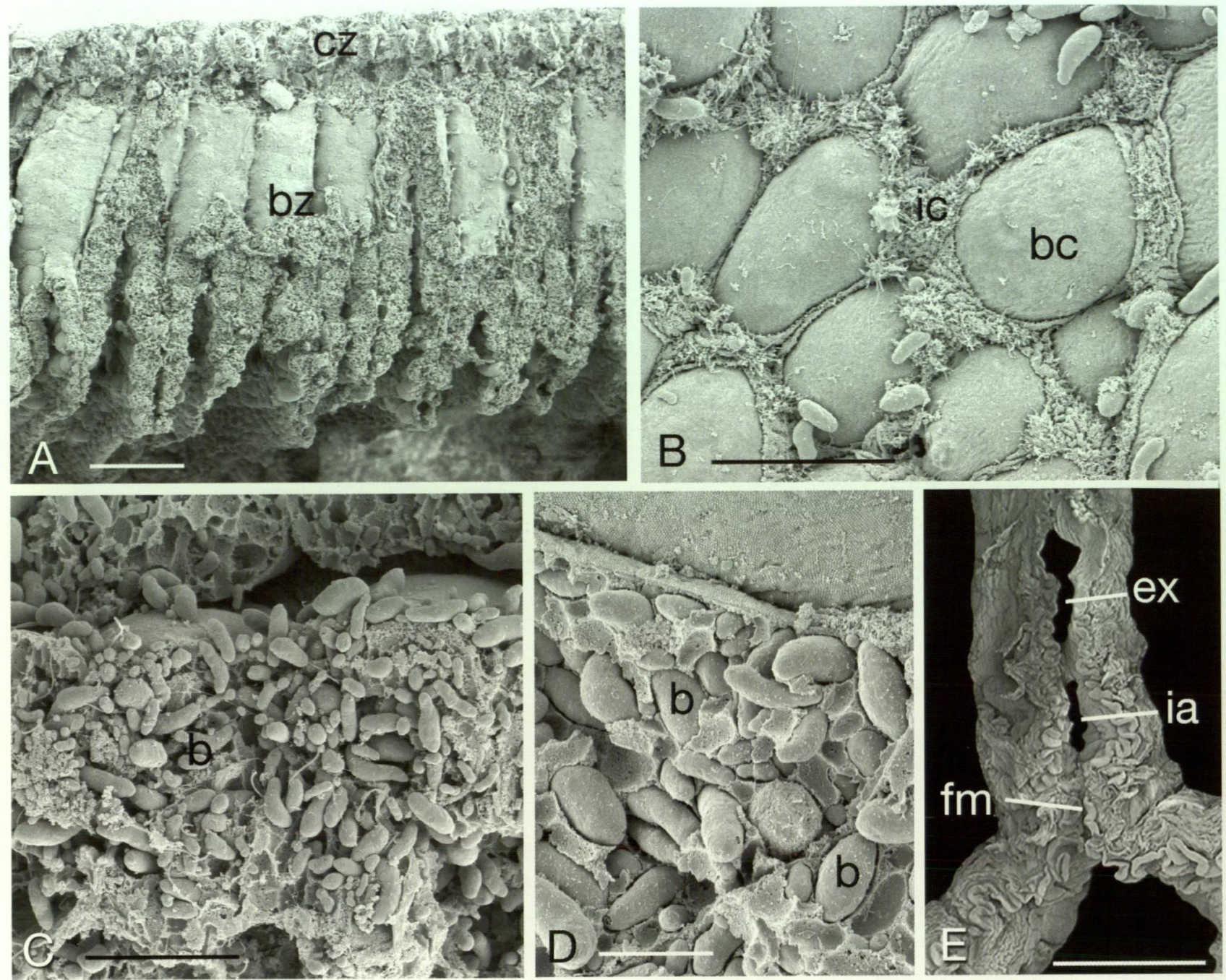

Figure 8 Bacteriocytes and posterior apertures of Pseudolucinisca lacteola, Esperance, Western Australia. SEMs of critical point dried preparations from glutaraldehyde - fixed tissue: A, section of ctenidal demibranch showing extensive abfrontal thickening of the bacteriocyte zone; B, surface of bacteriocytes with surrounding intercalary cells; $\mathrm{C}$, section of bacteriocytes containing abundant bacteria: D, bacteria in apical part of bacteriocyte; E, posterior apertures. Scale bars $A=100 \mu \mathrm{m} ; B=20 \mu \mathrm{m} ; C=10 \mu \mathrm{m} ; \mathrm{D}=5 \mu \mathrm{m} ; \mathrm{E}=2 \mu \mathrm{m}$. Abbreviations: $\mathrm{b}=$ bacteria; $\mathrm{bc}=$ bacteriocytes; $\mathrm{bz}=$ bacteriocyte $\mathrm{zone} ; \mathrm{cz}=$ ciliated $\mathrm{zone}$; $\mathrm{ex}=$ exhalant aperture, $\mathrm{fm}=$ fused mantle; ia = inhalant aperture; ic = intercalary cells.

by an indistinct sulcus. Hinge plate narrow, LV with two cardinal teeth, smaller anterior tooth, not always present, abuts against projecting lunule. RV with a single cardinal. Lateral teeth absent in both valves. Ligament long, narrow, set in shallow groove. Anterior adductor scar short, fairly broad, detached from pallial line for $1 / 3$ of length (Figure 3D), posterior adductor scar ovate. Pedal muscle scars strongly visible and separate from adductor scars. Pallial line discontinuous, divided into small blocks. Inner surface of shell dull, ventral margin finely denticulate with beaded appearance. Shell white to grayish white.

\section{Anatomy}

A single live-collected specimen from Esperance, Western Australia, was available for observations on gills and bacteriocytes. As in all studied Lucinidae (Taylor and Glover 2006), the ctenidia have single demibranchs with broad, closely spaced filaments. In section, there is a narrow, distal ciliated zone and a long, lateral zone comprising sheets of bacteriocytes, about $15-20 \mu \mathrm{m}$ in diameter (Figures 8A, B). These bacteriocytes are capped with short, uniform microvilli and separated by intercalary cells with spiky apical extensions (Figure 8B). The bacteriocytes are packed with short, rod-shaped bacteria 5-7 $\mu \mathrm{m}$ long and $2 \mu \mathrm{m}$ wide (Figures $8 \mathrm{C}$, D). These observations confirm the presence of bacteria in the ctenidia and the likely nutritional dependence on chemosymbiosis for P. lacteola.

The form of the posterior apertures and amount of mantle fusion ventral to the inhalant aperture have some potential in systematic studies of 


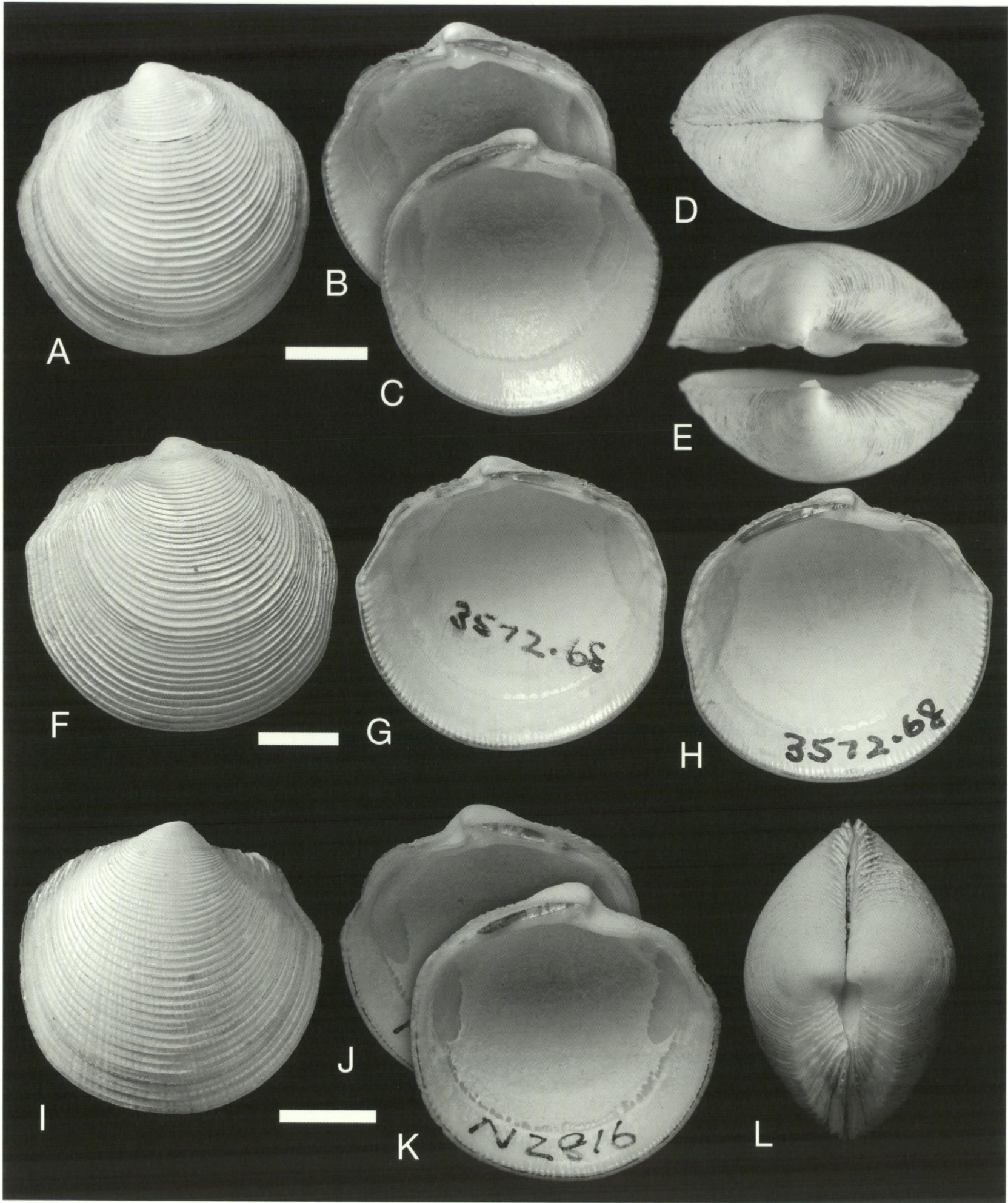

Figure 9 Pseudolucinisca wami new species. A-E, holotype (WAM S13399) Cockburn Sound, Fremantle, Western Australia: A, exterior left valve; B,C, interior of both valves; D, dorsal view; E, dorsal view with parted valves to show asymmetry of lunule; F-H, paratype (WAM S13400), Dunsborough, Geographe Bay, Western Australia: F, exterior of left valve; $\mathrm{G}$, interior of right valve; $\mathrm{H}$, interior of left valve; $\mathrm{I}-\mathrm{L}$, paratype (WAM S13396), Middle Channel, Houtman Abrolhos Islands: I, exterior of right valve; J, K, interiors of left and right valves; $\mathrm{L}$, dorsal view. Scale bars $=5 \mathrm{~mm}$. 
Lucinidae (Taylor and Glover 2006). The posterior apertures of Pseudolucinisca lacteola are shown in (Figure 8E); the inhalant aperture lacks papillae and there is a medium length of mantle fusion (fusion index 0.52; for method see Taylor and Glover 2002) compared to the highly fused Phacoides pectinatus (Gmelin 1791) at 0.78 and the short fusion of Codakia orbicularis (Linnaeus 1758) at 0.20 (Taylor and Glover 2006).

\section{Distribution}

This species is found from Portland, Victoria, and South Australia to Cape Leeuwin, Western Australia (Figure 11). Shells of P. lacteola recorded from beaches on Rottnest Island, off Fremantle, are probably derived from the late Quaternary deposits outcropping along the shores (see Hickman and Barnes 1999).

\section{Remarks}

See below for comparison with new species.

\section{Pseudolucinisca wami new species}

Figures 3F, 9, 10, 11

Callucina lacteola (Tate 1897): Slack-Smith 1990: 148.

Callucina (Pseudolucinisca) lacteola (Tate 1897): Taylor and Glover 2004: 262.

\section{Material examined}

\section{Holotype}

Australia: Western Australia: 1 shell with dried body (H 18.3, L 18.2, T 6.1), Fremantle, Cockburn Sound, 32 $11^{\prime} \mathrm{S}, 115^{\circ} 43^{\prime} \mathrm{E}, 29$ November 1972, L. Marsh (WAM S13399).

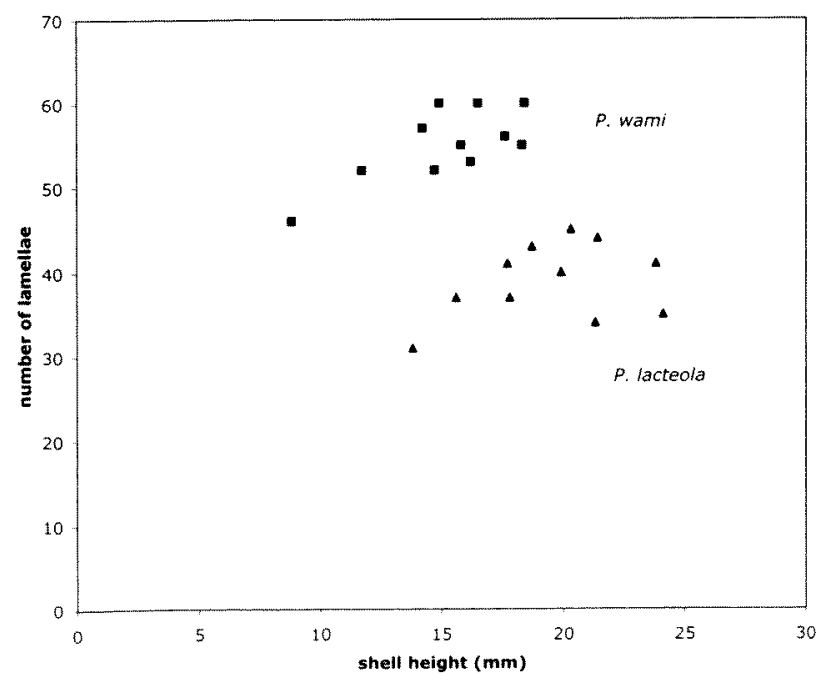

Figure 10 Scatter plot of number of commarginal lamellae against shell length for Pseudolucinisca lacteola and $P$. wami.
Paratypes

Australia: Western Australia: 1 shell (H 18.4 mm, L 19.7, T 6.0), Geographe Bay, Dunsborough,

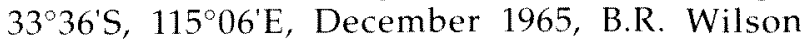
(WAM S13400); 1 shell (H 14.7, L 15.4, T 4.9), Abrolhos Islands, Middle Channel, $28^{\circ} 35^{\prime} \mathrm{S}$, $113^{\circ} 46^{\prime} \mathrm{E}$, March 1963, J. Seabrook, 03.1963 (WAM S13396).

\section{Other material examined}

Australia: Western Australia: Geographe Bay, $9 \mathrm{~m}$ (WAM); 3 miles $(4.8 \mathrm{~km}$ ) off Dunsborough, $54 \mathrm{ft}(16.5 \mathrm{~m})$ (WAM); Eagle Bay, Geographe Bay (WAM); Busselton Beach (BMNH); Palm Beach, Rockingham (WAM); Warnboro Sound (WAM); Cockburn Sound (WAM); west of Rottnest, $110 \mathrm{~m}$ (WAM); off northeast Rottnest Island, $22 \mathrm{~m}$ (BMNH); Green Island, off Grey (WAM); Cervantes, North Terin Bank (WAM); Jurien (WAM); Geraldton, Bluff Point. (WAM); Zeewyck Channel, Houtman Abrolhos Islands, 21 fathoms (38 m) (WAM); SW face of Beacon Island, Wallabi Group, Houtman Abrolhos Islands (WAM); E. side Wooded Island, Easter Group, Houtman Abrolhos Islands, 24 fathoms (44 m) (WAM); Middle Channel, Easter Group, Houtman Abrolhos Islands 21 fathoms (38m) (WAM); Bernier Island, Shark Bay (WAM); Boat Harbour, Carnarvon (BMNH); Exmouth (AMS); Dampier Archipelago, 32-43 m (BMNH); 78 miles $(125.5 \mathrm{~km}) \mathrm{NNE}$. of Port Hedland, $19^{\circ} 4.4^{\prime} \mathrm{S}, 119^{\circ} 4.4^{\prime} \mathrm{E}, 82 \mathrm{~m}$ (AMS).

\section{Diagnosis}

This species is very similar in general morphology to $P$. lacteola but differs in being smaller, with more densely-spaced commarginal lamellae (Figure 10) and more prominent radial striations in the interspaces between the lamellae.

\section{Description}

Shell small, $\mathrm{H}$ to 18.4 , $\mathrm{L}$ to 19.7 , subcircular (H/L mean 0.96 range $0.94-1.01$ ), solid, inflated $(T / L$ mean 0.33 range $0.30-0.35$ ) Umbones rounded, central, low. Sculpture of regularly spaced, low, narrow, commarginal lamellae (11-13 lamellae per $5 \mathrm{~mm}$ ); fine radial lines in interspaces over all shell. Anterior dorsal area demarcated by a low ridge and posterior area by a shallow sulcus. Lunule small, impressed, lanceolate, strongly asymmetrical, large arcuate flange of LV projecting into slot in RV (Figure 9E). Hinge plate narrow, LV with one larger posterior cardinal tooth and a deep socket, with a tiny anterior cardinal on lunular margin; lateral teeth absent; RV with single large cardinal, sometimes bifid, and no laterals. Ligament long, narrow, set in shallow groove. Anterior adductor muscle scar short, fairly broad, detached from pallial line for 


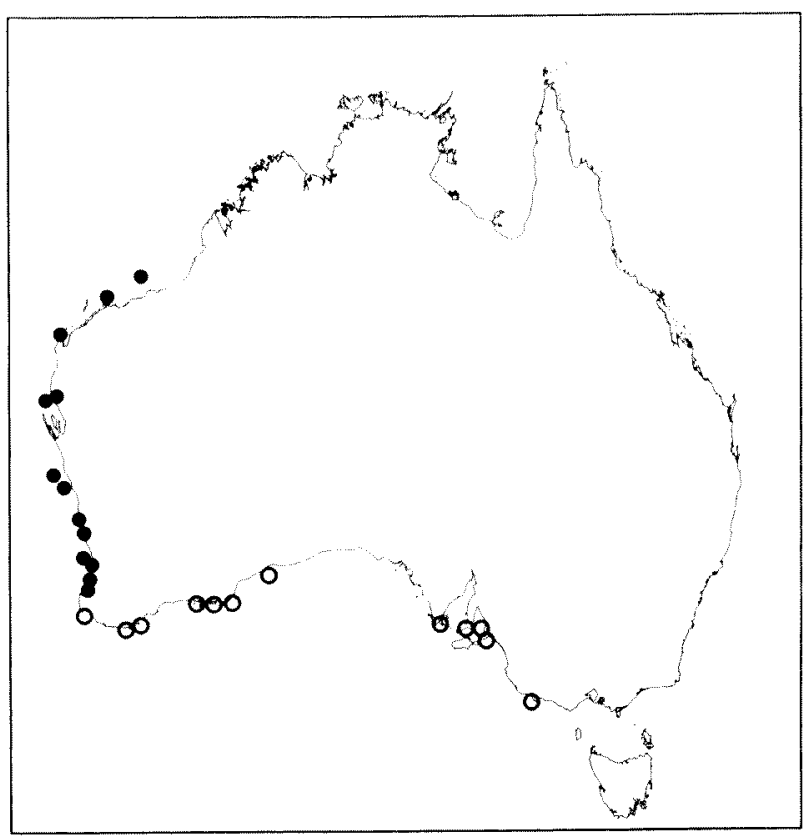

Figure 11 Map showing distribution of Pseudolucinisca species: Psemdolucinisca lacteola $(\bigcirc), P$. wami

one-third of length (Figure 3F); posterior scar ovate. Pedal muscle scars strongly visible and separate. Pallial line discontinuous, divided into small irregular blocks. Shell inner surface dull, glossy outside pallial line with fine radial grooves and marginal denticulations. Colour grey-white.

\section{Distribution}

This species is found in Western Australia from Geographe Bay to the North-West Shelf near Port Hedland (Figure 11).

\section{Remarks}

Pseudolucinisca wami and P. lacteola have contiguous ranges; $P$. lacteola is distributed from western Victoria to Cape Leeuwin and P. wami northwards from Geographe Bay to near Port Hedland. Bivalves from the southern parts of the range are generally larger than those from the north. Slack-Smith (1990: 148) remarked that specimens of Callacina lacteola (i.e. the new species, $P$. wami) from Shark Bay were generally smaller than those from more southerly localities.

\section{Etymology}

This species is named in recognition of the Western Australian Museum. The name is to be treated as a noun in apposition.

\section{DISCUSSION}

There is considerable misunderstanding in the generic assignments of small to medium sized Lucinidae that are subcircular in shape, with a sculpture of low, closely spaced commarginal lamellae and an absence of well-defined sulci or dorsal areas. A number of genera including Callucina, Callucinella, Callucinopsis and Epilucina have similar external morphology but differ in hinge, adductor muscle scar and other internal characters. For this reason, we have used in this paper a more narrowly defined concept of Callucima, based on characters of the type species, thereby excluding some of the fossils often assigned to Callucina but possessing lateral teeth. Pseudolucinisca is usually regarded as a subgenus of Callucina but there is no firm evidence that they are related, so we treat them as two distinct genera.

Although Callucina s.l. has been claimed as an ancient genus, older Mesozoic lucinids referred to Callucina (Chavan 1937-1938, 1959) all need re-evaluation and most can be considered as doubtful assignments, for instance Callacina olea (Vokes 1946: 46, plate 7, figures 14-17) from the Cretaceous (Aptian) of Lebanon has sculpture (coarse, sharp lamellae) and dentition (robust, posterior lateral tooth) unlike Callucina keenae. The small Lucina ripleyana Wade (1926: 82 plate 25 figures 19-21) from the Campanian Ripley Formation was assigned to Callucina by Chavan (1959) but has large anterior and posterior lateral teeth. Similarly, Lucina calmoni Pervinquière 1912 from the Maastrichtian of Tunisia, included in Callucina by Chavan (1938: 220), possesses two cardinal teeth in each valve and both anterior and posterior lateral teeth. Chavan (1959) subsequently placed this species in his new genus Callucinopsis.

From shell characters Bretsky (1976: 235 and figure 3) claimed a close relationship of Callucina with Parvilucina and placed Callucina as a stem group of a clade comprising Parvilucina, Lucinisca, Pleurolucina and Callucina. This proposal is yet to be tested by molecular methods. The usual inclusion of Pseudolucinisca as a subgenus of Callucina implies a close relationship. However, molecular results for Pseudolucinisca lacteola shows that it aligns near to the Anodontia clade and not with Lucinisca and many other shallow water lucinids (Williams et al. 2004; Taylor, Glover and Williams unpublished data). This result is incongruent with the classification of Chavan (1969) who placed Callucina and C. (Psendolucinisca) within the subfamily Lucininat and the Anodontia group in the Milthinae.

The distribution of Pseudolucinisca is restricted to southern and western Australia with two living species. For Callucina s.s there are three living species from the Indo-West Pacific province, C. winckworthi from Mauritius and the two new Australian taxa described here. On shell characters, the new Australian Callucina are 
closely similar to the western Atlantic Callucina keenae and it is reasonable, without other evidence, to group them in the same genus.

Western Australia is known to harbour populations of invertebrates regarded as relicts of the Cenozoic Tethyan Ocean, notably stygobiont fish and copepods (Knott 1993; Humphreys 1999; Jaume et al. 2001). Amongst marine molluscan examples (Beesley et al. 1998) are Campanile symbolicum (Iredale 1917), Neotrigonia spp. and Diastoma melanioides (Reeve 1849). Callucina species are known from the Palaeogene of Europe and North America and the Neogene of eastern North America (Bretsky 1976) and the Australian and Mauritius species may be a remnant of a former, wider distributional range. However, there is no known fossil record of the genus in the IndoWest Pacific. Similarly, fossil lucinids with shells superficially similar to Pseudolucinisca are known from the Miocene of southern France and Italy (Chavan 1959), although these all need critical reassessment.

\section{ACKNOWLEDGEMENTS}

Shirley Slack-Smith, Fred Wells and Corey Whisson (WAM), Ian Loch (AM), Sue Boyd (NMV), Wolfgang Ziegler (SAM) and Paul Callomon (ANSP) are thanked for help and access to collections. Some samples were collected during the Marine Biological Workshop at Esperance, 2003. We acknowledge Harry Taylor (BMNH) for the fine macrophotography and are grateful to The Natural History Museum, London for continuing support.

\section{REFERENCES}

Adams, A. (1855). Descriptions of twenty-five new species of shells from the collection of Hugh Cuming Esq. Proceedings of the Zoological Society of London 1855: 221-227.

Adams, A. and Angas, G.F. (1865). Two new species of shells, in the collection of George French Angas. Proceedings of the Zoological Society of London 1865: 54.

Beesley, P.L., Ross, G.J.B. and Wells, A. (1998). Mollusca: the southern synthesis. Fauna of Australia Volume 5 part A. CSIRO Publishing: Melbourne.

Bretsky S.S. (1976). Evolution and classification of the Lucinidae (Mollusca; Bivalvia). Palaeontographica Americana 8: 219-337.

Britton, J.C. (1970). The Lucinidae (Mollusca: Bivalvia) of the Western Atlantic Ocean. PhD dissertation, George Washington University. University Microfilms 71-12, 288.

Chavan, A. (1937-1938). Essai critique de classification des lucines. Journal de Conchyliologie 81: 237-281; 82: 215-241

Chavan, A. (1959). Quelques intéressantes subdivisions.
Cahiers Géologiques 53: 515-516.

Chavan, A. (1961). Deux genres de lamellibranches remarquables: Callucina et Parvilucina. Cahiers Géologiques 58-61: 561.

Chavan, A. (1969). Superfamily Lucinacea Fleming, 1828. In R.C. Moore (ed.), Treatise on Invertebrate Paleontology, Part N, Mollusca 6, Bivalvia, vol. 2: N491-N518, Geological Society of America and University of Kansas, Boulder, Colorado.

Chavan, A. (1971). Errata and revisions. In R.C. Moore (ed.), Treatise on Invertebrate Paleontology, Part N, Mollusca 6, Bivalvia, vol. 3: N1215, Geological Society of America and University of Kansas, Boulder, Colorado.

Cossmann, M. and Peyrot, A. (1909-1912). Conchologie néogènique de l'Aquitaine. Actes de la Société Linnéenne de Bordealix 63: 1-718.

Cotton, B.C. and Godfrey F. K. (1938). The Molluscs of South Australia. Part I. The Pelecypoda. South Australian Branch of the British Science Guild: Adelaide.

Cotton, B.C. (1961). South Australian Mollusca. Pelecypoda. South Australian Branch of the British Science Guild: Adelaide.

Dall, W.H. (1901). Synopsis of the Lucinacea and of the American species. Proceedings of the U.S. National Museum 23: 779-833.

Glover, E.A. and Taylor, J.D. (2001). Systematic revision of Australian and Indo-Pacific Lucinidae (Mollusca: Bivalvia): Pillucina, Wallucina and descriptions of two new genera and four new species. Records of the Australian Museum 53: 263-292.

Glover, E.A., Taylor, J.D and Slack-Smith, S.M. (2003). A new species and genus of lucinid bivalve from Western Australia (Bivalvia: Lucinidae). In: F.E. Wells, D.I.Walker and D.S. Jones (eds), The Marine Flora and Fauna of Dampier, Western Australia: 419-423. Western Australian Museum, Perth.

Hedley, C. (1916). A preliminary index of the Mollusca of Western Australia. Journal and Proceedings of the Royal Society of Western Australia 1: 152-226.

Hickman C.S. and Barnes, P.A.G. (1999). Fossil lucinid bivalves of Rottnest Island: anomalous Late Quaternary geographic distributions. In: D.I. Walker and F.E. Wells (eds). The Seagrass Flora and Fauna of Rottnest Island, Western Australia: 239-245. Western Australian Museum: Perth.

Humphreys, W.F. (1999). Relict stygofaunas living in sea salt, karst and calcrete habitats in arid northwestern Australia contain many ancient lineages. $I n: W$. Ponder and D. Lunney (eds), The Other $99 \%$. The Conservation and Biodiversity of Invertebrates: 219-227. Transactions of the Royal Zoological Society of New South Wales, Mosman.

Jaume, D., Boxshall G.A. and Humphreys W.F. (2001). New stygobiont copepods (Calanoida; Misophrioida) from Bundera sinkhole, an anchialine cenote on northwestern Australia. Zoological Journal of the Linnean Soctety, London 133: 1-24.

Knott, B. (1993). Stygofauna from Cape Range Peninsula, Western Australia: Tethyan relicts. Records of the Western Australian Museum, Supplement 45: 109-127.

Lamprell, K. and Whitehead, T. (1992). Bivalves of 
Anstralia. Crawford House Press: Bathurst.

Lamprell, K. and Healy, J. (1998). Binales of Australia Volume 2. Backhuys Publishers: Leiden.

Ludbrook N.H. (1955). The molluscan fauna of the Pliocene strata underlying the Adelaide Plains. Part 2 Pelecypoda. Transations of the Royal Socioty of South Alstralia 91: 93-109.

Ludbrook, N.H. (1978). Quaternary Molluses of the western part of the Eucla Basin. Geological Surey of Western Australia Bulletin 125: 1-286.

May, W.L. (1921). A checklist of the Mollusa of Tasmania. Government Printer: Hobart

May, W.L. (1958). Hhustrated index of Tasmanim shells (rowised by Macpherson. I.H.). Government Printer: Hobart.

Pervinquière, L. (1912). Études de Paléntologie Tunisionne 11 Gastropodes et Lamellibranches des Terrams Cretaces. Carte Géologique de la Tunisie. J. Lamarre et Cie: Paris.

Sacco, F. (1901). I molluschi de terreni terziarii de Pimonte e' della Liguria. Part 29. Carlo Clausen: Torino.

Slack-Smith, S. (1990). The bivalves of Shark Bay, Western Australia, In: P.F Berry, S.D. Bradshaw and B.R. Wilson (eds), Resonch in Shark Bay. Report of the FranceAlstrale Bicentenary Expedition Committee: $129-157$. Western Australian Museum: Perth.

Tate, R. (1897). Critical remarks on some Australian Mollusca. Transactions of the Royal Society of South Australia 20: 40-49.

Tavlor, J.D. and Glover, E.A. (1997a). A chemosymbiotic lucinid bivalve (Bivalvia: Lucinoidea) with periostracal pipes; functional morphology and description of a new genus and species. In: Wells, F. (ed.), The Marine flora and fann of the Houtman Abrolhos Islands, Western Australia: 335-361. Western Australian Museum: Perth.

Taylor, J.D. and Glover, E.A. (1997b). The lucinid bivalve genus Cartiolucina; systematics, anatomy and relationships (Mollusca: Bivalvia: Lucinidae). Bulletin of the Natural History Musem, Lonton, Zoology 63: $93-122$.
Taylor, J.D. and Glover, E.A. (2002). Lamollolucina: a new genus of lucinid bivalve with four new specios from the Indo-West Pacific. Jommal of Conchology 37 $317-336$.

Taylor, J.D. and Glover, E.A. (2004). Diversity and distribution of subtidal benthic molluses from the Dampier Archipelago, Western Australia; results of the 1999 dredge survey (DA2/99). In: D.S. Jones (ed.) Marine Boditersity of the Dampie' Archipelago Western Australin 1998-2002. Records of the Western Anstratian Muscum, Supplement 66: 247-291.

Taylor, J.D. and Glover, E.A. (2005). Cryptic diversity of chemosymbiotic bivalves: a systematic revision of worldwide Anodontin (Mollusca: Bivalvia: Lucinidae) Sustematics and Biodieersity 3: $281-338$.

Tavlor, I.D. and Glover, E.A. (2006). Lucinidae (Bivalvia) the most diverse group of chemosymbiotic molluscs. Zoological Jommal of the Limnan Soctety 148: 421-438.

Viader, R. (1951). New or unrecorded shells from Mauritius and its dependencies. Manrtims Institute Bulletin 3: 127-153.

Vokes, H. E. (1946). Contributions to the paleontology of the Lebanon mountains, Republic of Lebanon. Part 3. The pelecypod fauna of the "Olive Locality" (Aptian) at Abeih. Bulletin of the Anterican Musemm of Natural History 87: 143-215

Wade, B. (1926). The fauna of the Ripley Formation on Coon Creek, Tennessee. U.S. Geological Stricy Professional Paper 137: 1-272.

Williams, S.T., Taylor, J.D. and Glover, E.A. (2004). Molecular phylogeny of the Lucinoidea (Bivalvia): non-monophyly and separate acquisition of bacterial chemosymbiosis. Journal of Molluscan Studies 70 : $187-202$

Manuscript receided 1 Nowmber 2007 ; accepted $6 \mathrm{May} 2008$. 